\title{
The Factors Affecting Students' English Speaking Ability at Politeknik LP3i Medan
}

\begin{abstract}
Author:
Ramadani ${ }^{1}$

Sukri Hamdani ${ }^{2}$

Abstract: This study deals with the factors affecting students' English speaking ability at Politeknik LP3I Medan. It uses qualitative research design with a single case study to gain an understanding on this study. It is conducted descriptively. This

Afiliation:

Politeknik LP3I Medan ${ }^{1,2}$ study aims to know the factors affecting students' English speaking ability at Politeknik LP3I Medan. The subjects were 20 students (males and females) of Politeknik LP3I Medan. The

Corresponding email Ramadanijawa92@gmail.com instruments in this study were observation and interview. The theories of Brown (1994: 4) are divided some factors which affect speaking, they are Chronological Age, Grammar, Vocabulary,

Histori Naskah: Submit: 99-00-9999 Accepted: 99-00-9999 Published: 99-00-9999 Fluency, and Comprehension. There are three factors affecting students' English speaking ability at Politeknik LP3I Medan. They are fluency, vocabulary and English environment and an additional factor that found by researcher as a new insight in this research is English environment. Analysis of data clearly indicates that the students are using English at campus every day.

This is an Creative Commons License This work is licensed under a Creative Commons Attribution-NonCommercial 4.0 International License

keyword: definition of speaking, factors affecting speaking ability

\section{Introduction}

English is a global language which is used in such activities, education, technology, social status, and modernization. English is attractive attention for every field especially the education field in Indonesia. The schools and university level use English as the main subject and learn it in every study program. However, Indonesia is lower rank than India, Vietnam, and Hong Kong based on EF (Education First) English Proficiency Index 2017. Considering the importance of the languages, Indonesia's government has drawn up English as a foreign language that should be mastered by the students. By and large, an English teacher, educator or lecturer is an instructor and supervisor who understand the needs of students in English. There are four language skills in teaching English as the needs of students; they are; reading, listening, speaking, and writing. One of important skill is speaking. Frey (2007:16) adopted the speaking definition put forth by Cooper and Morreale : "Speaking is the uniquely human act or process of sharing and exchanging information, ideas, and emotions using oral language". Most of students are difficult to study English speaking because they have the problem in their pronunciation and lack of vocabulary. Speaking is the most important for students right now. Everybody knows someone to be able to speak English by their speaking. When the researcher did observation in the field, the researcher got the unique from Politeknik LP3I Medan, almost all of students at Politeknik LP3I Medan using English as their daily communication at campus. From that phenomenon, the researcher is interesting to conduct the research about what are the factors affecting students' English speakingability at Politeknik LP3I Medan
\end{abstract}

\section{Study of Literature \\ Definition of Speaking}

Fisher and Frey (2007:16) adopted the speaking definition put forth by Cooper and Morreale: "Speaking is the uniquely human act or process of sharing and exchanging information, ideas, and emotions using oral language. Whether in daily information interactions or in more formal settings, communicators are required to organize coherent messages, deliver them clearly, and adapt them to their listeners".

Fulcher (2003: 23-25) states that speaking is the verbal use of language to communicate with others. 
Speakers use languageto communicate their ideas, most speaking involves interaction with one or more participants. It means that effective speaking need to be able to progress language in their own heads and involves a good deal of listening, an understanding of how the other participants feeling, and knowledge of how linguistically to take turns or allow other to do so.

In addition, Hughes (2002:135) states that speaking is fundamentally an interactive task; speaking happens under real time in processing constrains and it is more fundamentally linked to the individually who produces it.

\section{Factor Affecting Speaking Ability}

The students should learn how to be communicative in speaking English. They learn more speaking skills and developsome attitude toward speaking achievement. Therefore, the speaker must know the topic of the conversation in order to give or share of their information.

To reach the target language, Brown (1994: 4) divided some factors which affect speaking, they are:

1. Chronological Age: Most students indicate that the age of beginning speaking success that is intellectual, personality, and social factor. Therefore, it is important for teacher to consider whether the students were ready to speak or not.

2. Grammar Grammar is the description of the structure of a language and the way in which linguistic unit such as words andphrases and combined to produce sentence in the language.

3. Vocabulary

Numan said that Vocabulary is more than lists of target language words. A spoken word is a sound of sequence of sound, which communicate in idea to the mind of another person. In order to communicate those ideas precisely, a speaker should express them with precise word rather than general word.

4. Fluency

Looks at fluency as the ability to fill the time with talk. In this definition, the speaker can use the time of talking most productively. The definition of fluency is derived as the ability of an individual to speak without undue hesitation.

5. Comprehension

Comprehension is the minds act or power of understanding. It means that the comprehension will be as contrasted with the ability to perceive and pronounce words without reference to their meaning. Clark and clark make a simple meaning of comprehension as the building the meaning from sounds. It means what the listener hear and understand from a speaker is to show his comprehension

\section{Methodology}

The research method of this study was descriptive qualitative. Bogdan and Biglan (1992:30) said, 'qualitative research is descriptive. The data collection are in the form of words rather than numbers. Qualitative method explains the social phenomena that acquire naturally, it doesn't manipulate the certain situation. In this study the researcher used observation and interview as the instrument of collecting data. The observation was used to know or to find the phenomena that occur at Politeknik LP3I Medan.

\section{Result and Discussion}

This study applied qualitative data. The data were taken from analyzing the interview from the participants after analyzing the data. The researchers found that there are three findings of factors affecting students' English speaking ability at Politeknik LP3I Medan from this study. They are fluency, vocabulary and English environment. 


\section{Fluency}

The researcher found the data that fluency is one of factor in speaking English at Politeknik LP3I Medan as the followingdata :

$R \quad$ : Does there an "English Environment" in the campus Improveyour English?

SU : Yes, the existence of the English environment is significantly improving my

English which was halting now increase more andmore fluently.

ID : With the English environment, it is very helpful to improve and

Launch my English, because the English environment forces us to speak English.

From the conversation above we know that the lecturer has a unique way to launch English in the campus. From thisexpression ".....now more improved and more fluently the student is fluent in using English at campus. The lecturer will

Give penalties to students who do not use English at campus. This means that students will get used to using and speakingEnglish at campus.

\section{Vocabulary}

The following is the data that students find new word everyday caused by implementing speaking English every day atcampus.

$R \quad:$ What changes do you get when you apply speak English in the campus?

$A R \quad:$ The changes that I got were very drastic day by day my words increased, and my knowledge in English alsoincreased.

From the conversation above, we can see there are benefits in implementing the English environment on campus. Fromthe expression ".......day by day my words increased " it means that vocabulary also one of factor in affecting students English speaking. In this campus, the lecturer implements English every day.

\section{English environment}

Brown (1994:4) divided some factors which affect speaking, they are Chronological Age, Grammar, Vocabulary, Fluency, Comprehension. There is a new insight from this study. The researcher found the factor affecting students English speaking is English environment. It has significant affect to students in improving their English speaking, we can see from the following conversation.

$R \quad:$ What changes do you have when there is an implementation of English at campus?

ARP : The changes I got when the English was implemented is my English becomes more active,

MF : The changes that I have experienced have increased greatly, at I was very unhappy about English since school, butwith the implementation I kept trying to upgrade myself to be able to compete with other friends.

From the conversation above, we can see there is benefit in implementing of English environment at 
campus. The data shows that there is positive result in implementing this program and then there is unique one from this implementation of English environment. When the researcher interviewed the informants, the researcher get the data as following.

$R \quad:$ Is there something special if you don't use English at the campus?

$S \quad$ : If we don't use English then we will be on Fines if in class or affect the score obtained in the English environment Assessment for each student.

SU : If we do not use English then our score It becomes low because the English environment score is taken60\% for English.

YH : Yes, there is something, which is to get the low English environment score and it will be influential in English.

From the conversation above we know that the lecturer has unique way to improve students' English speaking skill. Thelecturer will give the punishment to students who don't use English at campus and it also influences on their score because English environment has big effect to their final score. It means that the students will compete to get high score by speaking English at campus

\section{Conclusion}

Based on findings from the results of the study, it can be concluded that:

There are three findings that found by researcher, namely: fluency, vocabulary and English environment. English environment is a new insight from this study because there is a gap between theory and reality in the field. The use of the English environment program significantly improved the speaking skills Students of Politeknik LP3I Medan, as evidenced by the interview test conducted on students. The influence of the English environment program motivates students to improve theiruse English, and is able to add to their vocabulary.

\section{References}

Brown, Gillian and Yule, George. 1999. Teaching the spoken Language. Cambridge University Press

Hughes, Rebecca. 2006. Spoken English, TESOL, and applied Linguistics:Challenges for Theory and Practice.

Great Britain: CPI Antony Rowe Aye, K. K. \& Phyu, K. L.(2015). Developing students' speaking skill Throughshort stories. Yangon University of Education ResearchJournal, 5(1), 11.

Bahadorfar, M. \& Omidvar, R. (2015). Technology in teaching speaking skill.Acme International Journal of Multidisciplinary Research,2(4), 9-13.

Bashir, M., Azeem M., \& Dogar, A. H. (2011). Factor effecting students' English speaking skills. British Journal of Arts and Social Sciences, 2(1), 34-50.

Brown, H.D (1994). Teaching by Principle. Englewood Cliffs, NJ; Prentice Hall. Koba, N., Ogawa, N., \& Wilkinson, D. (2000). Using the community language learning approach to cope with language anxiety. The Internet TESL Journal, 6(11).

Larsen-Freeman, D., \& Anderson, M. (2011). Techniques and principles in language teaching (3rd ed.). London, England: Oxford University Press 
Richards, J. C., \& Rodgers, T. S. (2002). Approaches and methods in language teaching ( $2^{\text {nd }}$ ed.). New York, NY: Cambridge University Press

Moleong, Lexy J.1995. Metodologi Penelitian Kualitatif. Bandung: PT. Remaja Rosdakarya

Miles, MB, Huberman, A.M, dan Saldana, J. qualitative Data Analysis, A Methods Sourcebook, Edition 3. USA: Sage Publication.. 